\title{
Caracterização dos solos da bacia do Rio Ligeiro (PR) na estabilidade de taludes
}

\author{
Ney Lyzandro Tabalipa ${ }^{1} \&$ Alberto Pio Fiori ${ }^{2}$
}

\begin{abstract}
Resumo O objetivo principal do presente trabalho é caracterizar os solos e analisar as condições de estabilidade das encostas da bacia do Rio Ligeiro no município de Pato Branco, Sudoeste do Paraná, empregando um modelo matemático associado à utilização de técnicas de mapeamento temático em ambiente SIG. A análise para determinação dos índices de segurança foi efetuada através de método determinístico, baseado no conceito de equilíbrio limite. O modelo matemático adotado baseia-se na distribuição das forças atuantes em uma vertente infinita e foi considerada a influência da saturação do solo nas encostas. $\mathrm{O}$ trabalho envolveu a caracterização geotécnica em campo, ensaios em laboratório, e trabalhos de escritório. Como resultado da interação de todos os parâmetros, obtiveram-se valores de Fator de Segurança para cada vertente. Constatou-se, através do estudo, que as áreas mais susceptíveis a escorregamentos estão associadas a encostas com solos do tipo Cambissolo e Neossolo encontrados em áreas com declividade superior a 20\%. Áreas estáveis aparecem com maior frequência nas regiões de solos Latossolos e Nitossolos, localizados em terrenos de baixa declividade, onde o perigo de ocorrência de deslizamento é praticamente nulo. Observou-se ainda que, as áreas de ocorrência de Cambissolos e Neossolos correspondem a $84 \%$ das instabilidades da bacia quando o solo se encontra totalmente saturado. De acordo com os resultados alcançados no estudo, verifica-se que a bacia do Rio Ligeiro apresenta áreas com instabilidade susceptíveis a escorregamentos, como consequência dos fatores ambientais, do meio físico e da ocupação antrópica das encostas, com remoção da vegetação.
\end{abstract}

Palavras-chave: Encosta, Solo, Fator de Segurança.

\begin{abstract}
Characterization of soil of basin of Ligeiro river, Pato Branco (PR) for stability in slope. The main objective of this work is to characterize the soil and analyse the conditions for stability of slopes of the basin of Rio Light in the municipality of Pato Branco, southwest of Parana, using a mathematical model associated with the use of techniques for thematic mapping in GIS environment. The analysis for determining the rates of safety was accomplished through deterministic method, based on the concept of balance limit. The mathematic model is based on the distribution of forces engaged in an endless strand and was considered the influence of the saturation of soil on the slopes. This work involved the characterization in geotechnical field, testing in the laboratory and office functions. As a result of the interaction of all parameters, returned to values of Factor Security for each side. It was through this study, that the areas most likely to slip the slopes are associated with soil and the type Cambisol and Neossol found in areas with a slope above 20\%. Areas stable appear more frequently in the areas of land and Oxisols and Nitossols, located in areas of low slope, where the risk of occurrence of creep is virtually nil. It was also observed that the areas of occurrence of Cambisols and Neosols account for $84 \%$ of unstable areas of the basin where the soil is completely saturated. According to the results achieved in this study, it appears that the basin of Rio Light presents areas of instability, likely to slip, as a result of environmental factors, the physical environment and the occupation of manmade slopes, with removal of vegetation.
\end{abstract}

Keywords: Slope, Soil, Factor Security.

INTRODUÇÃo O uso e a ocupação do solo nas cidades brasileiras por muito tempo ocorreram sem a adequada consideração dos aspectos fisiográficos e ignorando as reais potencialidades e limitações das áreas a serem ocupadas.

Acompanhando esta ocupação desenfreada que não obedece a qualquer critério de planejamento em relação aos recursos naturais e ao bem estar da população, surgem inúmeros problemas, tais como: como erosões e assoreamentos, escorregamentos, enchentes, recalques de solo, esgotamento dos recursos hídricos, contaminação por disposição incorreta de resíduos, entre outros, que consomem grandes recursos, além de muitas vezes, colocarem em risco a vida da população local. Entre os problemas mencionados, um de grande preocupação no Brasil, são os escorregamentos nas encostas, devido a maior possibilidade de perdas de vidas e vultosos prejuízos econômicos.

Os escorregamentos podem ser definidos como todo e qualquer movimento que envolva solo, solo e rocha ou apenas rocha que em função de um conjunto de fatores, tais como: elevadas declividades, altos índices de pluviosidade, antropismo etc., sofrem deslocamentos induzidos pelo agente gravidade.

1 - Departamento de Construção Civil, Universidade Tecnológica Federal do Paraná, Pato Branco (PR), Brasil. E-mail: ntabalipa@yahoo.com.br 2 - Departamento de Geologia, Setor de Tecnologia, Universidade Federal do Paraná, Curitiba (PR), Brasil. E-mail: fiori@ufpr.br 
Uma massa de solo pode ser considerada como um conjunto de partículas sólidas e espaços vazios de tamanhos e formas variadas que, por sua vez, podem estar preenchidos com água, ar ou ambos.

Estudos sobre solos demonstram que sua origem e evolução sofrem influência do clima (chuvas e temperatura), materiais de origem, organismos vegetais e animais, relevo e tempo (Salomão \& Antunes 1998).

A investigação do comportamento geotécnico dos solos vem se intensificando dentro da Geologia de Engenharia, inclusive no campo da estabilidade de taludes, uma vez que, os parâmetros e propriedades do solo influencia direta ou indiretamente a susceptibilidade aos movimentos de massa e ao tipo de mecanismo de instabilização (Wolle 1988).

Para Guidicini \& Nieble (1983) as propriedades mais significativas dos materiais, na discussão de problemas de estabilidade, são o ângulo de atrito e a coesão de solos e rochas, que podem ser facilmente encontrados em laboratório através do ensaio de cisalhamento direto.

A ruptura dos solos é quase sempre um fenômeno de cisalhamento. A resistência ao cisalhamento de um solo pode ser definida como a máxima tensão de cisalhamento que o solo pode suportar sem sofrer ruptura, ou a tensão de cisalhamento do solo no plano em que a ruptura estiver ocorrendo (Pinto 2002).

Conforme Kozciak (2005) o ângulo de atrito e a coesão, parâmetros determinantes da resistência ao cisalhamento, variam bastante, dependendo da gênese e das características dos solos.

Para Franciss \& Rocha (1998) a avaliação feita com relação à resistência ao cisalhamento, é definida em função dos parâmetros $c$ (coesão) e $\phi$ (ângulo de atrito) das descontinuidades e a relação entre a resistência que pode ser mobilizada e o esforço a que ela estará submetida é chamado de coeficiente de segurança.

O ângulo de atrito interno é o ângulo máximo que um determinado material pode assumir sem que haja rompimento de seu estado inercial. Pode ser definido como o ângulo cuja tangente constitui a razão entre as forças de resistência ao deslizamento, ao longo do plano da encosta, com as componentes das forças favoráveis ao movimento, exercidas sobre este plano.

Sob a denominação genérica de atrito interno de um solo, inclui-se não só o atrito físico entre as partículas, que se pode traduzir como a maior ou menor facilidade de deslizamento de uma partícula em relação à outra, como também o atrito fictício proveniente do entrosamento das partículas (Barata 1994).

Segundo (Caputo 1988) a coesão é uma característica típica de solos muito finos (argilas e siltes), distinguindo-se a coesão aparente, resultante da pressão capilar da água contida no solo, e que age como se fosse uma pressão externa de sucção, e a coesão verdadeira, devido às forças eletroquímicas de atração de partículas de argila e depende de fatores como a física do solo e a química coloidal.

Uma série de outros parâmetros e propriedades dos solos influencia, direta ou indiretamente, suas suscetibilidades aos movimentos de massa e ao tipo de mecanismo da instabilização atuante. Entre eles destacam-se: peso específico, porosidade, índice de vazios, mineralogia, granulometria, plasticidade, permeabilidade e compressibilidade.

O objetivo principal do presente trabalho é apresentar uma análise da estabilidade das vertentes da bacia do Rio Ligeiro no município de Pato Branco, Sudoeste do Paraná, caracterizando os tipos de solos dessa área.

CARACTERIZAÇÃO DAÁREA DE ESTUDO A bacia do Rio Ligeiro, com área de $44 \mathrm{~km}^{2}$, está localizada no município de Pato Branco, no Sudoeste do Estado do Paraná, entre as coordenadas UTM (Universal Transversal de Mercartor), em quilômetros, $7.092 \mathrm{a}$ $7.104 \mathrm{~N}$ e 328 a 338E (Fig. 1).

A distância da sede do município a Curitiba é de aproximadamente $433 \mathrm{~km}$, e o acesso à área, partindo de Curitiba, pode ser efetuado pela rodovia BR-476 que liga Curitiba a Horizonte. A partir de Horizonte, segue-se pela BR-280, em direção oeste, passando por Palmas, Clevelândia, Mariópolis e Pato Branco.

Toda a área estudada acha-se sujeita, conforme a classificação de Koppen, ao clima do tipo $\mathrm{CFb}$, com temperatura média do mês mais quente inferior a $22^{\circ} \mathrm{C}$. A região encontra-se sob o regime climático chuvoso, mesotérmico, úmido a superúmido sem estação seca, de verões frescos e geadas severas bastante frequentes no inverno, com média de precipitação anual de $2.109 \mathrm{~mm} / \mathrm{ano}$.

A área mapeada acha-se compreendida entre as altitudes de 600 a $1.000 \mathrm{~m}$ e apresenta uma topografia de relevo suavemente ondulado com vales abertos na porção leste, sendo que na faixa oeste predominam as superfícies levemente aplainadas.

A caracterização e descrição dos solos se embasaram no Levantamento de Reconhecimento dos Solos do Sudoeste do Estado do Paraná, EMBRAPA (1974), adaptado para a nova classificação da EMBRAPA (1999). Assim sendo, na área em estudo, ocorrem solos das ordens Latossolo (Roxo Álico), Nitossolo (Terra Roxa Estruturada), Cambissolo (Distrófico), Neossolo (Solos Litólicos Distróficos ou Álicos) e Depósitos Aluvionares.

A constituição geológica da região é relativamente simples, representado pelas rochas basálticas do Grupo São Bento, Formação Serra Geral, que recobrem inteiramente a área mapeada, sendo formadas por derrames de lavas do grande vulcanismo fissural ocorrido 


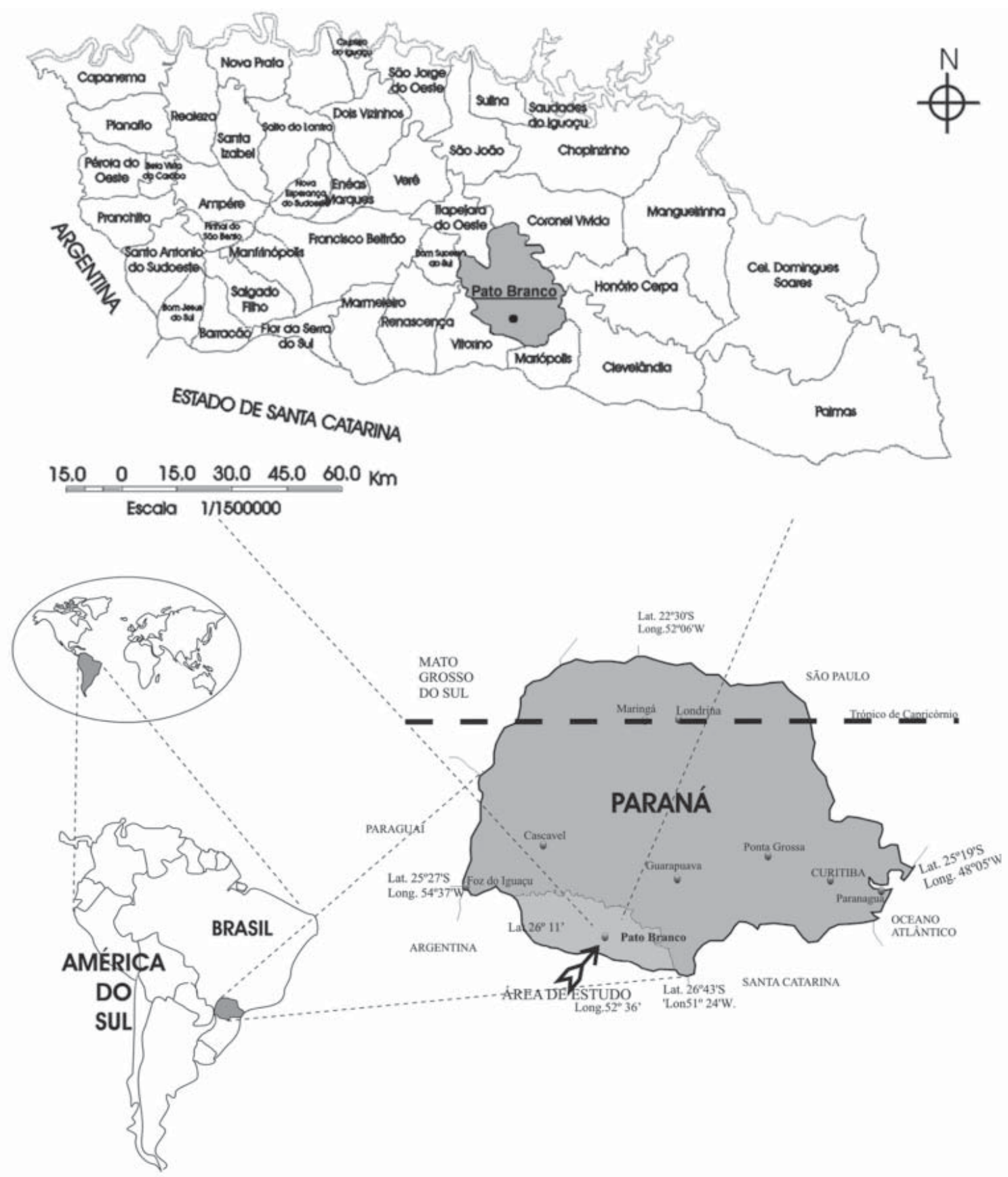

Figura 1 - Localização do município de Pato Branco no estado e na região sudoeste do Paraná.

durante a Era Mesozoica, CPRM (1996). As rochas são do tipo basalto toleíticos com intercalações de arenito e rochas vulcânicas ácidas, ambas intercaladas por diques e sills de diabásio.

$\mathrm{Na}$ área de estudo a vegetação pertence a Floresta Subtropical Perenifólia que se caracteriza por ser mais resistente ao frio e menos exuberante que as florestas tropicais, sendo que as árvores são geralmente de porte médio, havendo, no entanto, locais com domínio de indivíduos de grande porte e de grande diâmetro.

Esta floresta em geral, apresenta três níveis ou estratos, sendo o superior constituído por araucária, imbuia, cedro, canela e outras espécies de grande porte; o médio por pimenteira, erva-mate, caroba, bracatinga e outras; e o inferior por ervas, arbustos e gramíneas (EMBRAPA 1984).

MATERIAIS E MÉTODOS Para a execução deste estudo, o trabalho foi dividido em três etapas. A primeira parte consistiu em fazer uma revisão das bibliografias sobre os aspectos naturais da área da bacia do Rio Ligeiro, caracterizando fisiograficamente a área de estudo. Além disso, agregou-se o material necessário para preparar uma base cartográfica digital. A segunda 
parte consistiu em fazer um reconhecimento da área, registrando em fotografias os aspectos gerais da região e coletando amostras de solo deformadas e indeformadas para posterior determinação de parâmetros geotécnicos em laboratório. Na última etapa elaborou-se um banco de dados com as informações obtidas, e aplicou-se a equação para os cálculos do Fator de Segurança, partindo-se para a análise dos resultados encontrados e produção dos mapas temáticos. Nesta fase também se elaborou o Mapa de Fator de Segurança.

Para extração das informações básicas, tais como: curvas de nível, vias de acesso, rede de drenagem principal, pontos cotados, entre outros, foram utilizadas as cartas topográficas de "Pato Branco" MI - 2862/2 (1981) e "Mariópolis" MI - 2862/4 (1980) da Diretoria de Serviço Geográfico do Exército na escala 1:50.000 e uma Base Planialtimétrica do Perímetro Urbano de Pato Branco, na escala 1:10.000.

$\mathrm{Na}$ sequência foi elaborado o Mapa de Uso e Ocupação do Solo por meio da classificação da imagem do satélite QUICKBIRD de dezembro de 2005, baseando-se no critério proposto pelo IBGE (2006), sendo as classes de uso do solo divididas em: Agricultura, Campo, Urbana, Capoeira, Florestas e Corpo d'água. O próximo passo foi organizar as informações em forma de banco de dados.

Com a finalidade de completar o reconhecimento da área estudada realizaram-se várias visitas a campo, descrevendo os perfis dos solos, coletando-se amostras de solo para laboratório, esclarecendo dúvidas sobre os alvos observados nas imagens de satélite para o seu mapeamento.

Para determinar o comportamento geotécnico de cada tipo de solo da bacia estudada fez-se uma análise in situ dos solos, possibilitando assim fazer uma classificação aproximada do solo no campo. Na sequência, realizaram-se ensaios em laboratório com amostras de solos deformadas e indeformadas, que incluíram ensaios de análise granulométrica, teor de umidade, limites de ATTERBERG (Limite de Liquidez e Limite de Plasticidade), ensaios de cisalhamento direto (para obter peso especifico aparente, coesão e ângulo de atrito interno) e de permeabilidade.

A escolha dos pontos de amostragem de solo foi realizada de forma a abranger todos os tipos de solos existentes na bacia, tendo por base o Mapa Pedológico existente em Tabalipa (2002), criado a partir da definição pedológica sugerida pela EMBRAPA (1999). O parâmetro adotado para a escolha dos pontos foi a facilidade de acesso e a distribuição na bacia de forma a obter uma boa representatividade na área, conforme visualizada na figura 2 . Também se utilizou de trabalhos anteriores realizados na área, tais como: sondagens geológicas a percussão - SPT (Standard Penetration
Test), avaliação geológica e geotécnica do município realizado pela MINEROPAR e investigações de passivos ambientais nos solos dos postos de gasolina do Município.

Os pontos utilizados para se realizar a descrição dos solos da bacia estudada estão divididos da seguinte forma: pontos de 1 a 9, coleta amostras deformadas e indeformadas, sendo realizada a descrição do solo in situ e ensaios nos laboratórios da UFPR (LAME e LabSed); pontos 10 a 13, coleta de apenas amostras deformadas que foram analisadas do laboratório de solos da UTFPR de Pato Branco; pontos 14 a 16 retirados do trabalho realizado pela MINEROPAR - Avaliação Geológica e Geotécnica para o Planejamento Territorial e Urbano do Município de Pato Branco, 2006; e finalmente, os pontos 17 a 21 que foram retirados de Estudos de Passivos Ambientais em Postos de Gasolina do Município de Pato Branco, 2004.

Descrição dos Solos Em pontos pré-determinados da área de estudo os solos foram descritos in situ, considerando aspectos gerais do afloramento, localização na área, relevo, drenagem, existência ou não de erosão e situações de risco, uso atual, além da cor e da textura, conforme figura 3 . As amostras de solos também foram analisadas em laboratório.

Para a descrição dos solos deste trabalho, levaram-se em questão as várias condições ambientais que determinam as características peculiares de cada solo, tais como: relevo, declividade, cobertura vegetal, clima e materiais de origem.

O Mapa Pedológico (Fig. 4) foi gerado com base no levantamento de solos realizado por Tabalipa (2002) e nos trabalhos de campo realizados ao longo desta pesquisa. A nomenclatura foi definida segundo critério estabelecido pela EMBRAPA (1999).

Conforme o Mapa Pedológico, na área em estudo, ocorrem solos das seguintes ordens:

LATOSSOLO (ROXO ÁLICO) Solos formados a partir de rochas eruptivas básicas, com horizonte B latossólico e não hidromórficos. Possuem coloração arroxeada, muito profundos e friáveis, porosos e acentuadamente drenados. São solos com avançado estágio de intemperização, com baixa diferenciação de horizontes, muito evoluídos, como resultado de enérgicas transformações no material constitutivo. A maior parte da classe é composta por solos muito profundos, normalmente com mais de $2 \mathrm{~m}$ de espessura, não sendo rara, entretanto, a ocorrência de solos com mais de $5 \mathrm{~m}$ de profundidade. Os solos desta classe ocupam, frequentemente, superfícies de declives suaves, comumente entre 2 e $8 \%$, ocorrendo de maneira menos intensa, em relevos com declives entre 8 e $15 \%$, sendo raras as ocorrências 

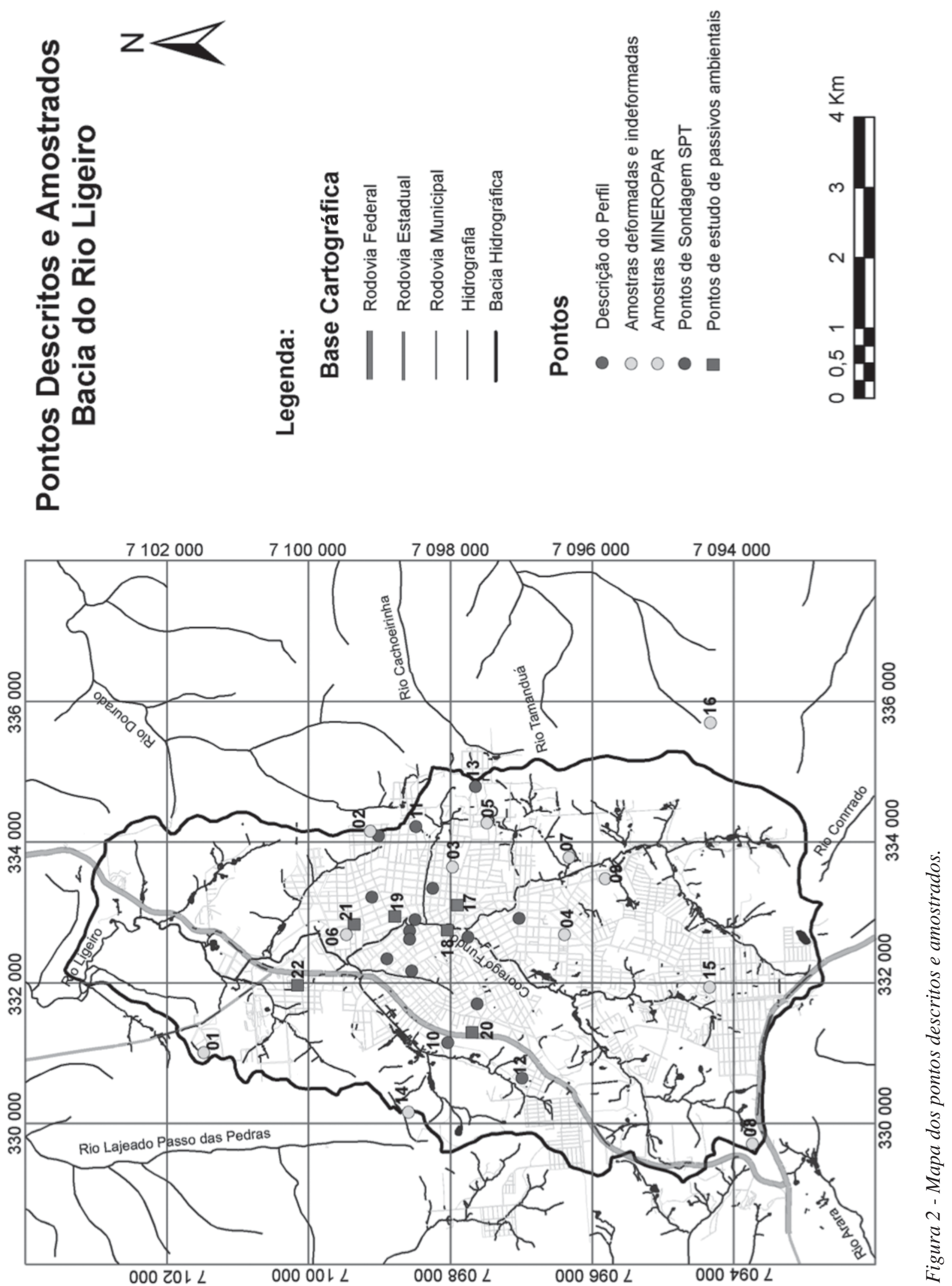


\begin{tabular}{|c|c|c|c|c|c|c|}
\hline \multirow[b]{2}{*}{ PONTO 1} & \multirow{2}{*}{$\begin{array}{l}\text { AMOSTRA } \\
\text { coordenadas }\end{array}$} & \multicolumn{2}{|c|}{$2.0269 .06(\mathrm{~A})$} & \multirow{2}{*}{$\begin{array}{c}\text { ALTITUDE (m } \\
799\end{array}$} & \multirow{2}{*}{$\begin{array}{l}\text { TIPO DE SOLO: } \\
\text { classificação conforme } \\
\text { EMBRAPA (1999) }\end{array}$} & \multirow{2}{*}{$\begin{array}{c}\text { LRa } \\
\text { Latossolo Roxo } \\
\text { Álico }\end{array}$} \\
\hline & & $\begin{array}{c}\mathbf{x} \\
\mathbf{x} \\
331.004 \\
\end{array}$ & \multirow[t]{2}{*}{$\begin{array}{c}\mathbf{y} \\
7.101 .504 \\
\end{array}$} & & & \\
\hline & & & & \multicolumn{3}{|c|}{ DESCRIÇÃO in situ } \\
\hline & & & & Situa & $\begin{array}{l}\text { Amostra: Indeformada e D } \\
\text { Localização: UTFF } \\
\text { Relevo: Ondulad } \\
\text { ção: Terço médio da encost } \\
\text { e erosão não apare } \\
\text { Uso atual: campc } \\
\text { or: Vermelho escuro } 2,5 \mathrm{YR} \\
\text { ular moderada e ligeirament } \\
\text { Textura: Argilosa }\end{array}$ & $\begin{array}{l}\text { boa drenagem } \\
\text { te } \\
\text { plástico, friável }\end{array}$ \\
\hline \multirow{2}{*}{ PONTO 10} & AMOSTRA & \multicolumn{2}{|c|}{ PERFIL 01 (2002) } & ALTITUDE (m) & \multirow{2}{*}{$\begin{array}{l}\text { TIPO DE SOLO: } \\
\text { classificação conforme } \\
\text { EMBRAPA (1999) }\end{array}$} & \multirow{2}{*}{$\begin{array}{c}\text { TRd } \\
\text { Terra Roxa } \\
\text { Estruturada } \\
\text { Distrófica } \\
\end{array}$} \\
\hline & coordenadas & $\frac{\mathbf{x}}{331.113}$ & $\begin{array}{c}y \\
7.098 .087\end{array}$ & 778 & & \\
\hline \multicolumn{7}{|c|}{ DESCRIÇÃo in situ } \\
\hline & & & & \multicolumn{3}{|c|}{$\begin{array}{c}\text { Amostra: Deformada } \\
\text { Localização: Bairro Bela Vista, corte de estrada } \\
\text { Relevo: forte ondulado } \\
\text { Situação: Solo exposto em barranco, Terço médio da } \\
\text { encosta, boa drenagem e erosão não aparente } \\
\text { Uso atual: pastagem } \\
\text { Cor: Bruno forte } 7,5 \text { YR } 4 / 6 \text { moderada, média em blocos } \\
\text { angulares, pegajoso e ligeiramente plástico, friável, } \\
\text { transição difusa e plana } \\
\text { Textura: Argilosa }\end{array}$} \\
\hline \multirow{3}{*}{ PONTO 11} & AMOSTRA & \multicolumn{2}{|c|}{ PERFIL 02 (2002) } & ALTITUDE (m) & \multirow{3}{*}{$\begin{array}{c}\text { TIPO DE SOLO: } \\
\text { classificação conforme } \\
\text { EMBRAPA (1999) } \\
\end{array}$} & \multirow{3}{*}{ itossolo Eutrófico } \\
\hline & \multirow{2}{*}{ coordenadas } & $\mathbf{x}$ & $\mathrm{y}$ & \multirow{2}{*}{764} & & \\
\hline & & 334.182 & 7.098 .500 & & & \\
\hline \multicolumn{7}{|c|}{ DESCRIÇÃo in situ } \\
\hline & & & & \multicolumn{3}{|c|}{$\begin{array}{c}\text { Amostra: Deformada } \\
\text { Localização: Bairro La Salle } \\
\text { Relevo: forte ondulado } \\
\text { Situação: Terço médio da encosta, boa drenagem e erosão } \\
\text { laminar } \\
\text { Uso atual: cultura de milho } \\
\text { Cor: Bruno avermelhado escuro } 2,5 \text { YR } 3 / 3 \text { argiloso, forte a } \\
\text { média granular, pouco plástico e pouco pegajoso } \\
\text { Textura: Argilo Arenosa }\end{array}$} \\
\hline \multirow[b]{2}{*}{ PONTO 5} & AMOSTRA & \multicolumn{2}{|c|}{$2.0267 .06(\mathrm{~F})$} & ALTITUDE (m & \multirow{2}{*}{$\begin{array}{l}\text { TIPO DE SOLO: } \\
\text { classificação conforme } \\
\text { EMBRAPA (1999) }\end{array}$} & \multirow{2}{*}{$\begin{array}{c}\text { Cambissolo } \\
\text { Eutrófico }\end{array}$} \\
\hline & coordenadas & $\frac{x}{334.269}$ & $\begin{array}{c}\mathbf{y} \\
7.097 .543\end{array}$ & 841 & & \\
\hline & & & & ESCRIÇÃO in sit & & \\
\hline 3 & 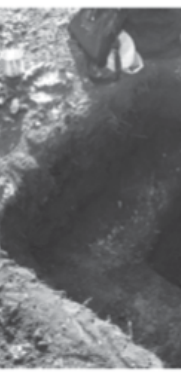 & & & $\begin{array}{l}\text { Situação } \\
\text { Cor: } \mathrm{Br} \\
\text { blocos }\end{array}$ & $\begin{array}{l}\text { Amostra: Indeformada e Def } \\
\text { Localização: bairro La S } \\
\text { Relevo: Ondulado } \\
\text { Terço superior da encosta, } \\
\text { erosão não aparente } \\
\text { Uso atual: terreno balo } \\
\text { uno avermelhado } 5 \text { YR } 4 / 4 \text { f } \\
\text { angulares pegajoso e ligeira } \\
\text { friável, transição gradual e } \\
\text { Textura: Argilosa }\end{array}$ & $\begin{array}{l}\text { mada } \\
\text { e drenagem e } \\
\text { a, média em } \\
\text { gular plástico, }\end{array}$ \\
\hline
\end{tabular}

Figura 3 - Descrição dos solos da área de estudo feita in loco. 

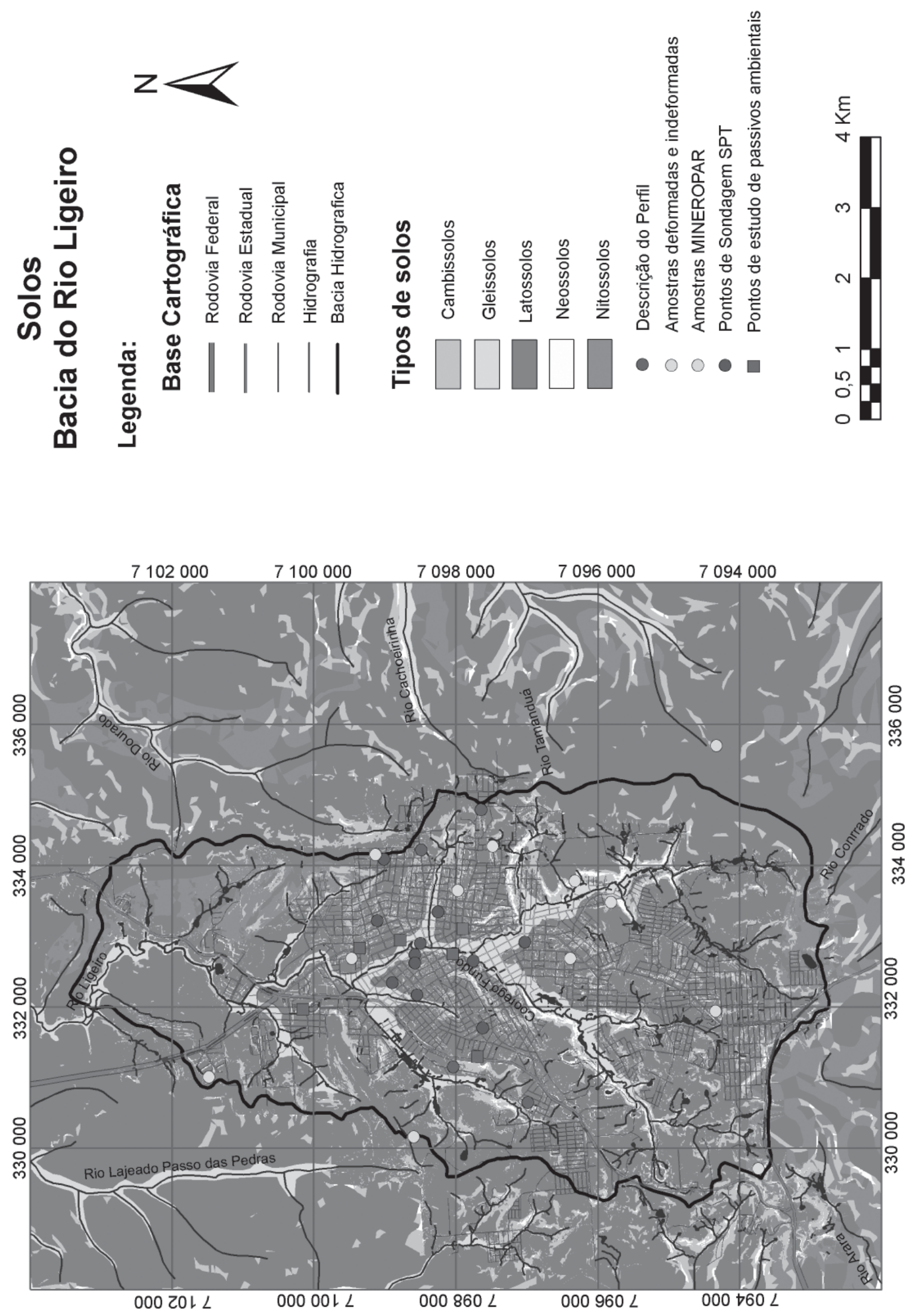
de declividades superiores a 15\%. São encontrados em altitudes bastante variadas, desde $200 \mathrm{~m}$ até acima de $900 \mathrm{~m}$

NITOSSOLO (TERRAROXA ESTRUTURADA) Compreende solos constituídos por material mineral, não hidromórfico, profundos, bem drenados, de coloração variando de vermelho a brunada predominantemente cauliníticos, com baixo gradiente textural. Esses solos ocorrem em áreas de relevo ondulado, com 8 a $20 \%$ de declividade ou em relevo forte ondulado, com 20 a $40 \%$ de declive. Menos frequentemente, ocupam superfícies de declive suaves ou, em casos extremos, em superfícies com mais de $40 \%$ de declive. São encontrados desde $240 \mathrm{~m}$ de altitude até $900 \mathrm{~m}$.

CAMBISSOLO (DISTRÓFICO) Compreendem solos minerais não hidromórficos, pouco desenvolvidos, com pedogênese pouco avançada e evidenciada pelo desenvolvimento da estrutura do solo, ausência, ou quase ausência, da estrutura da rocha. Essa classe é composta por solos pouco evoluídos, possivelmente devido à topografia acidentada ou ao material de origem bastante resistente ao intemperismo, ou tão jovens, que o tempo de atuação dos processos pedogenéticos não foi suficiente para uma intemperização mais profunda do solo. Mesmo possuindo boas características físicas, tais como as relacionadas à porosidade, permeabilidade, drenagem e floculação das argilas, esses solos são bastante susceptíveis a problemas geotécnicos, especialmente nas áreas de topografia acidentada. Ocorre em relevo montanhoso de vertentes íngremes, com declividades superiores a $20 \%$, as quais estão sujeitas à erosão.

\section{NEOSSOLO (SOLOS LITÓLICOS DISTRÓFICOS} OU ÁLICOS) Compreende solos constituídos por material mineral ou por material orgânico pouco espesso, com pequena expressão dos processos pedogenéticos em consequência da baixa intensidade de atuação desses processos. Apresentam rochas consolidadas pouco ou nada meteorizadas de características do próprio material. Ocorrem em locais de topografia acidentada, normalmente em relevo forte ondulado e montanhoso este tipo de solo está sujeito a queda de blocos e erosão, cujo processo impede o acúmulo de sedimentos em superfície, exigindo o cuidado de restringir a área apenas a preservação da vegetação natural. Os solos litólicos são encontrados em altitudes que variam desde $50 \mathrm{~m}$ até mais de $1.000 \mathrm{~m}$ e ocupam uma pequena faixa nos topos de morros. Nestes solos existe dificuldade da ocupação urbana, uma vez que, a implantação da infraestrutura enterrada é trabalhosa e elevado custo.
DEPÓSITOS ALUVIONARES Na área no mapa de solos estão cartografados os depósitos de sedimentos recentes que ocupam as áreas de fundo de vale. Estes depósitos são formados predominantemente por sedimentos imaturos, argilosos a arenosos, inconsolidados provenientes da decomposição das rochas basálticas, carreados para as drenagens pelas águas das chuvas, com proporções variáveis de matéria orgânica de coloração castanha a cinza escura.

Esses depósitos ocupam áreas de relevo plano nas baixadas, com nível freático raso ou aflorante, com dificuldade de escoamento pela ausência de declividade, agravando o problema de assoreamento das drenagens e enchentes.

Determinação de Fator de Segurança $O$ modelo matemático adotado no trabalho teve por base a distribuição das forças atuantes em um talude de extensão infinita, avaliando a influência da vegetação, clima, da água e das propriedades físicas e mecânicas do solo, através do Fator de Segurança.

A metodologia quantitativa realiza uma análise de perigo de escorregamento em função da determinação de valores numéricos de fatores de segurança, que permitem verificar a possibilidade de ocorrência de escorregamento em encostas, considerando os índices físicos e as propriedades mecânicas do solo, além de alguns parâmetros da vegetação. A figura 5 mostra a decomposição das forças que tendem a movimentar a massa de solo encosta abaixo e das forças resistentes ao mesmo que atuam como um freio a essa movimentação.

Para a aplicação da metodologia quantitativa na presente pesquisa, utilizou-se a análise do equilíbrio das forças atuantes em uma encosta, através da aplicação da equação de Fatores de Segurança $\left(F_{S}\right)$.

Utilizando os parâmetros para determinar o Fator de Segurança, caso de solo saturado, $\left(h_{1}=0\right.$ e $\left.h_{2}=Z\right)$ e incluindo os parâmetros de cobertura vegetal (contribuição da raiz para a coesão do solo, e a tensão que são submetidas às raízes como forças resistentes ao movimento; força do vento atuando sobre a copa das árvores, como força solicitante; o peso das árvores tanto como força resistente como solicitante) a equação utilizada pode ser definida como:

$$
F s=\frac{\left(C_{s}+S_{r}\right)+\left[\left(Z \cdot \gamma_{s u b}+P_{a}\right) \cdot \cos ^{2} i+T \cdot \operatorname{sen} \theta\right] \cdot \operatorname{tg} \phi+T \cdot \cos \theta}{\left[\left(Z \cdot \gamma_{s u b}+Z \cdot \gamma_{a}+P_{a}\right) \operatorname{sen} i+F_{v e}\right] \cdot \cos i}
$$

Onde:

$F_{S}=$ Fator de Segurança;

$C_{S}=$ coesão do solo;

$S_{r}=$ contribuição da raiz para a coesão do solo;

$Z=$ profundidade do solo; 


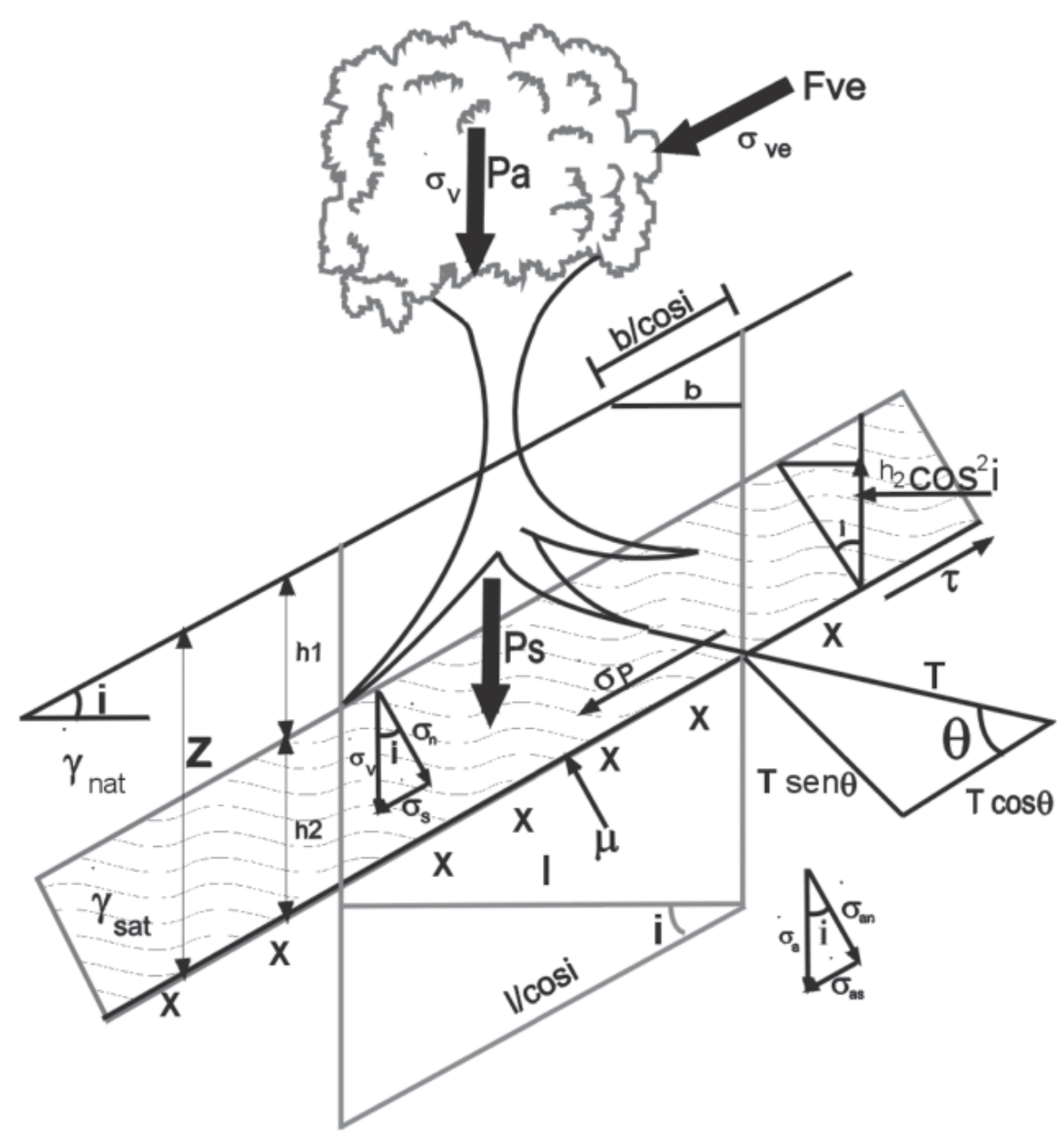

Figura 5 - Principais fatores que influenciam na análise de vertentes e forças atuantes. Fonte: Fiori \& Carmignani (2001).

$\gamma_{\text {nat }}=$ peso específico natural do solo;

$\gamma_{\text {sub }}=$ peso específico do solo submerso;

$\gamma_{a}=$ peso específico da água;

$P_{a}=$ peso das árvores sobre o solo;

$F_{v e}=$ força exercida pelo vento nas árvores;

$\phi=$ ângulo de atrito interno do solo;

$i$ = ângulo de inclinação da vertente;

$T=$ tensão das raízes.

Para a confecção do mapa de índices de segurança das encostas, foram estabelecidas nove classes de intervalo de Fator de Segurança, sendo estas as seguintes (Tab. 1):

Os Mapas de Fatores de Segurança das encostas foram gerados, inicialmente, a partir da interpolação dos mapas temáticos (declividade, mapa de uso e ocupação do solo, orientação da encosta e mapa de solos), utilizando Sistemas de Informação Geográficas e observando a suscetibilidade de cada tipo de solo, ao escorregamento, através dos resultados obtidos pela equação de Fatores de Segurança, conforme esquema mostrado na figura 6.
Já em relação com a saturação do solo, optou-se por considerar três possibilidades: considerar o solo natural, ou quase totalmente seco; considerar o solo não

Tabela 1 - Definição das classes de cada intervalo de Fator de Segurança, considerando $F_{S}$ de estabilidade igual a 1,5, determinado pelo DNER (1996) como padrão.

\begin{tabular}{|c|c|c|}
\hline Intervalos de $\boldsymbol{F}_{S}$ & Classes & Diagnóstico \\
\hline $0<F_{S}<1$ & 1 & \multirow{2}{*}{ Instabilidade } \\
\hline $1 \leq F_{S}<1,5$ & 2 & \\
\hline $1,5 \leq F_{S}<2$ & 3 & Estabilidade crítica \\
\hline $2 \leq F_{S}<3$ & 4 & Boa estabilidade \\
\hline $3 \leq F_{S}<4$ & 5 & Alta estabilidade \\
\hline $4 \leq F_{S}<5$ & 6 & \multirow{4}{*}{ Excelente estabilidade } \\
\hline $5 \leq F_{S}<8$ & 7 & \\
\hline $8 \leq F_{S}<10$ & 8 & \\
\hline$F_{S} \geq 10$ & 9 & \\
\hline
\end{tabular}



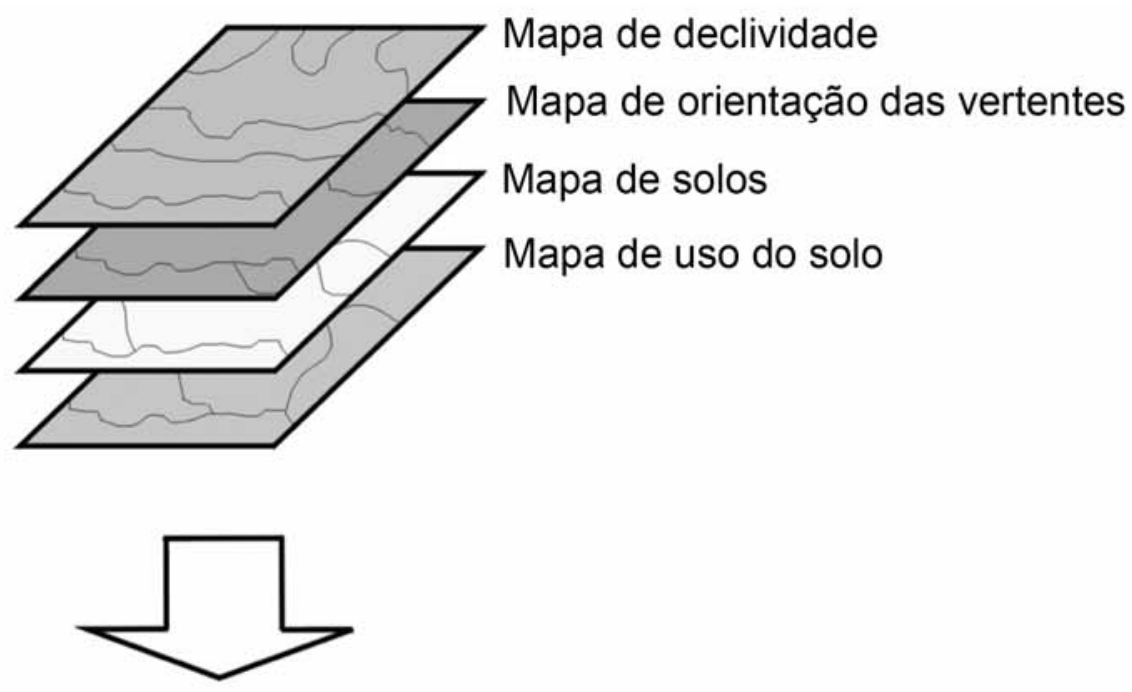

\section{Overlay - Interseção}
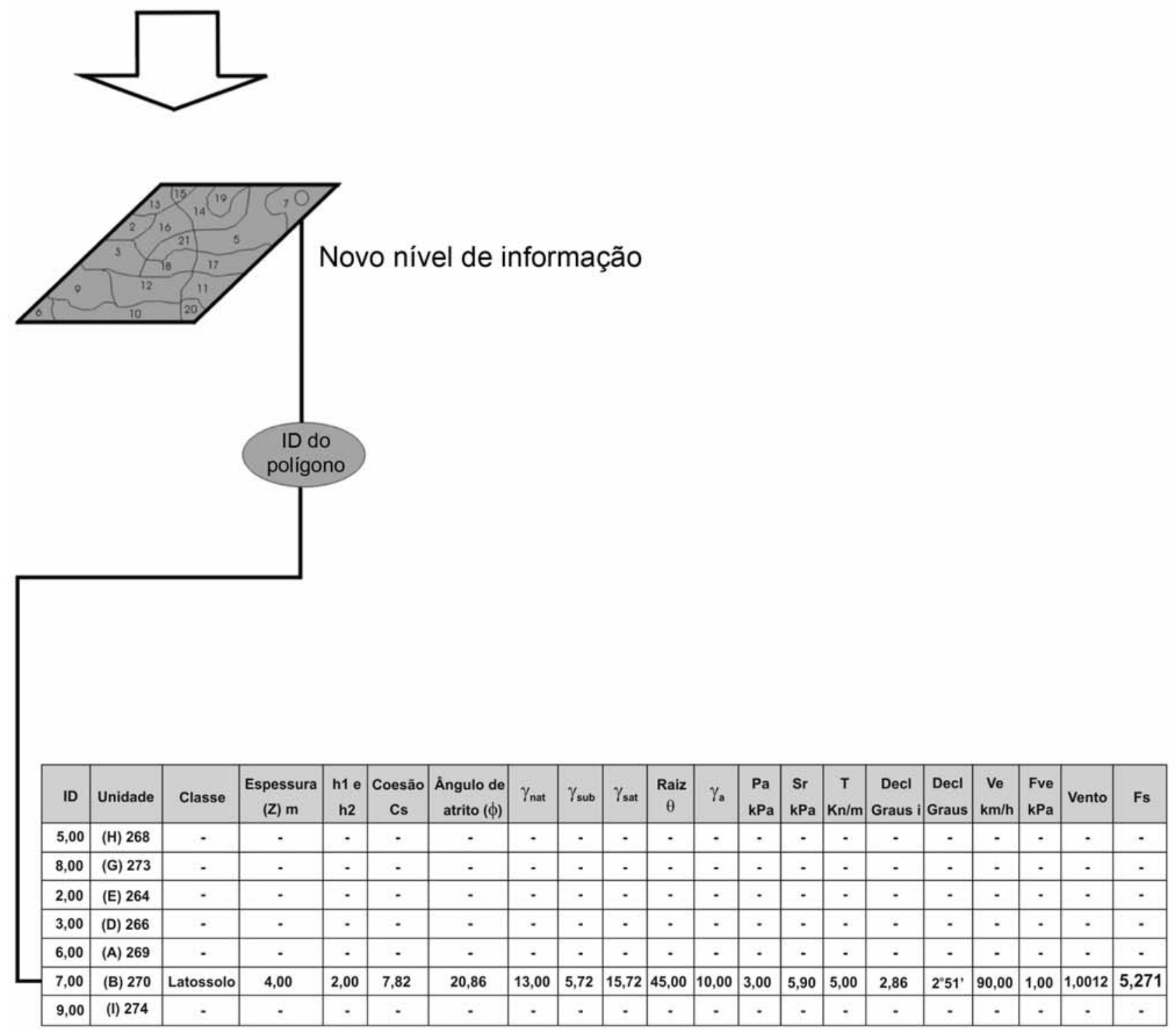

Figura 6 - Esquema das atividades realizadas para cálculo do fator de segurança. Fonte: modificado de Kozciak (2005). 
saturado, para uma saturação de $50 \%$; e considerar o solo saturado, indiferente da espessura do solo.

RESULTADOS E DISCUSSÕES Uma vez determinada todas as variáveis que atuam no processo de estabilidade de uma encosta, aplicou-se o modelo matemático, obtendo diferentes valores de Fator de Segurança nas simulações realizadas.

As áreas instáveis aparecem predominantemente sobre as áreas dos solos Neossolos e Cambissolos. Já a classe de zonas estáveis aparece com maior frequência nas áreas de solos Latossolos e Nitossolos.

$\mathrm{Na}$ bacia estudada os solos apresentam os valores de instabilidade descritos na tabela 2, sendo que os valores de instabilidade variaram conforme a saturação do solo.

Os Latossolos apresentaram grande estabilidade devido, principalmente, à pequena declividade que possuem. Quando se aumentou a declividade e a saturação do solo, surgiram áreas instáveis cobertas com esses tipo de solo.

A bacia estudada apresenta os seguintes tipos de solo: 2,86\% de Neossolos, 6,42\% de Nitossolos, $14,55 \%$ de Cambissolos e 76,17\% Latossolos, conforme tabela 3.

Do total de áreas de Latossolo $(76,17 \%$ da bacia), apenas uma pequena porção $(1,36 \%)$ apresentou Fs menor que 1,5 para solos Saturados, reduzindo para $0,09 \%$ para não saturados e $0,02 \%$ para solo seco.
Os Nitossolos representam apenas $6,42 \%$ da bacia, sendo que desse total, $0,99 \%$ se torna instável quando o solo estiver saturado, reduzindo para $0,05 \%$ para solo não saturado e $0,01 \%$ para solos naturais ou secos.

Os Neossolos apesar de representarem apenas $2,86 \%$ da bacia, a menor quantidade de um tipo de solo, são os que apresentaram as maiores quantidades de áreas instáveis de um solo. Aproximadamente 38,62\% dos Neossolos se tornam instáveis quando saturados, passando para $8,00 \%$ quando não saturado e $1,44 \%$ em estado seco.

Apesar das áreas cobertas com Neossolos apresentarem maiores porcentagens de instabilidade, e declividade mais acentuada, esses solos possuem valores de $F_{S}$ maiores do que os Cambissolos, ou seja, são solos mais estáveis que os Cambissolos. Este fato se deve principalmente a pouca evolução dos Neossolos, apresentando um horizonte B incipiente.

Nas áreas de ocorrência de Cambissolos, 14,55\% da área, observa-se que quando o solo estiver Saturado, $33,57 \%$ se tornará instável, diminuindo para 1,22\% para solos Não Saturados e 0,06\% para solos Naturais ou Secos.

As áreas correspondentes a Cambissolos e Neossolos correspondem a $84 \%$ das áreas instáveis da bacia.

Considerando a vertente com umidade natural (seco) e sem vegetação apenas os solos da classe Cambissolo, com declividade entre 55 a $60 \%$ apresentaram Fator de Segurança abaixo de $1,5\left(1,0<F_{S}<1,5\right)$.

Tabela 2 - Valor das áreas instáveis em relação ao tipo de solo, dependendo da saturação do solo.

\begin{tabular}{ccccc}
\hline Tipo de Solo & $\begin{array}{c}\text { Total da área da } \\
\text { bacia } \\
\mathbf{( \% )}\end{array}$ & $\begin{array}{c}\text { Quantidade de área instável } \\
\text { em relação ao tipo de solo } \\
\text { quando Saturado } \\
\mathbf{( \% )}\end{array}$ & $\begin{array}{c}\text { Quantidade de área instável } \\
\text { em relação ao tipo de solo } \\
\text { quando Não Saturado } \\
\mathbf{( \% )}\end{array}$ & $\begin{array}{c}\text { Quantidade de área instável } \\
\text { em relação ao tipo de solo } \\
\text { quando Natural ou Seco } \\
\text { (\%) }\end{array}$ \\
\hline Cambissolo & 14,55 & 33,57 & 1,22 & 0,06 \\
\hline Neossolos & 2,86 & 38,62 & 8,00 & 1,44 \\
\hline Nitossolos & 6,42 & 0,99 & 0,05 & 0,01 \\
\hline Latossolo & 76,17 & 1,36 & 0,09 & 0,02 \\
\hline
\end{tabular}

Tabela 3 - Área correspondente a cada classe de solo.

\begin{tabular}{ccc}
\hline Tipo de Solo & $\begin{array}{c}\text { Total } \\
\left(\mathbf{k m}^{\mathbf{2}}\right.\end{array}$ & $\begin{array}{c}\text { Total da área da bacia } \\
\mathbf{( \% )}\end{array}$ \\
\hline Cambissolo & 5,80 & 14,55 \\
\hline Neossolos & 1,14 & 2,86 \\
\hline Nitossolos & 2,56 & 6,42 \\
\hline Latossolo & 30,36 & 76,17 \\
\hline
\end{tabular}

Considerando a vertente como não saturada, apresentaram $F_{S}<1,5$ os solos Cambissolos com declividade entre 40 e $60 \%$ e Neossolos com qualquer declividade.

Finalmente considerando o solo saturado, apresentaram $F_{S}<1,5$ os solos Cambissolos com declividade entre 30 e $60 \%$, Neossolos com qualquer declividade e Nitossolos e Latossolo com declividade superior a 20\%. 
A área ocupada pelos Depósitos Aluvionares apresentaram grande estabilidade por encontrar-se em relevo plano, não sendo realizado cálculos de $F_{S}$ na região coberta por essa classe de solo.
A figura 7 mostra um comparativo do Fator de Segurança da mesma área (Bairro Industrial) nas três hipóteses adotadas: sem a presença de água (seco), não saturado (grau de saturação em 50\%) e saturado
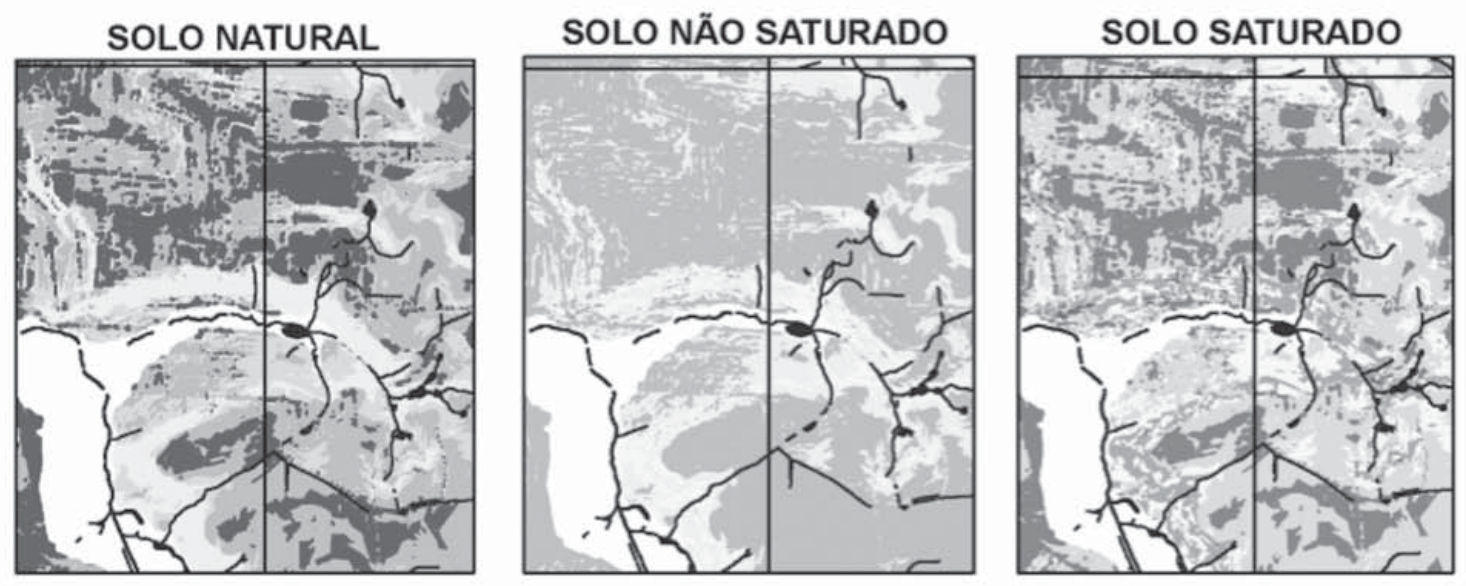

\section{FATOR DE SEGURANÇA}
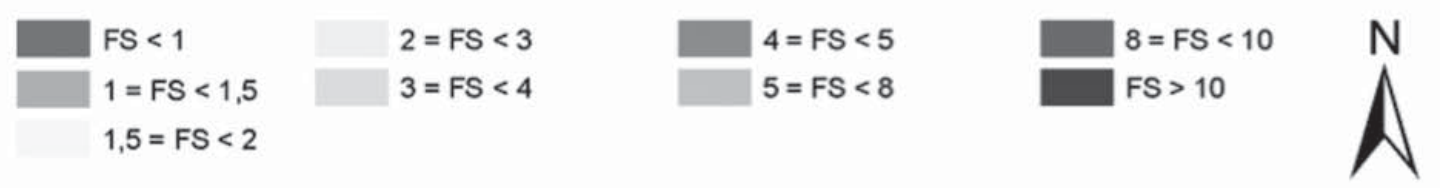

\section{DECLIVIDADE}
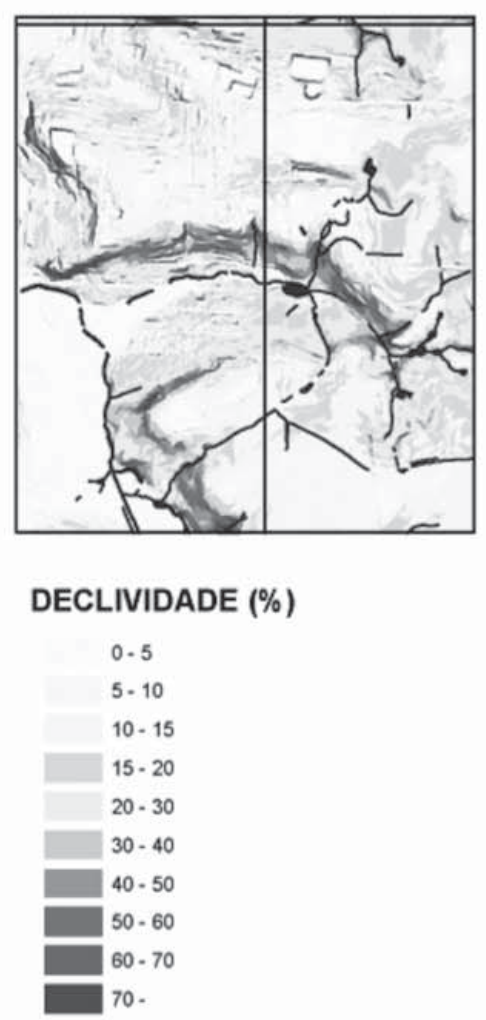

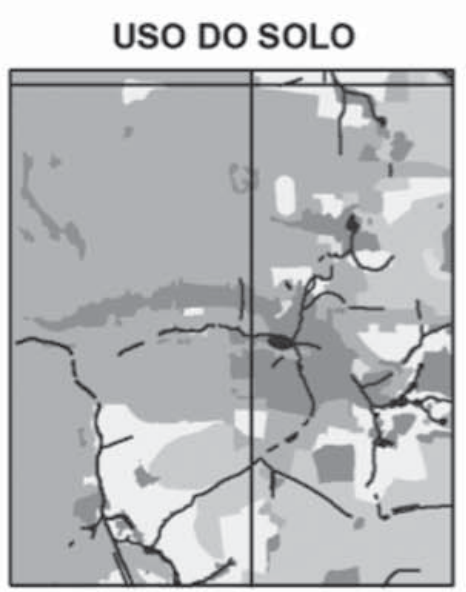

USO DO SOLO

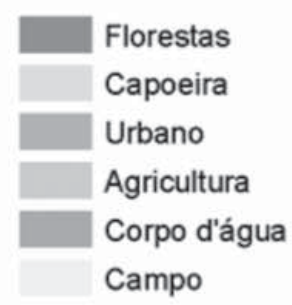

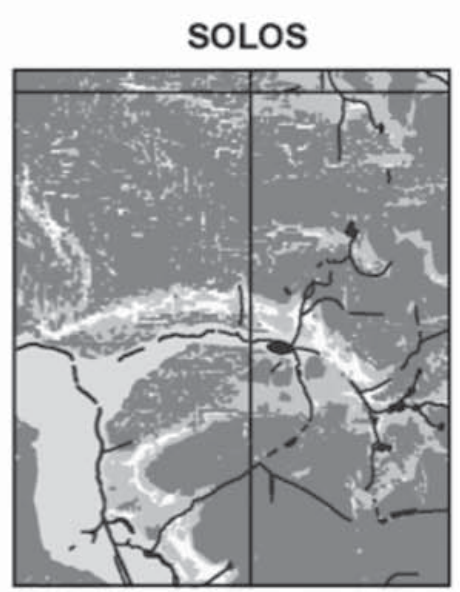

CLASSES DE SOLOS

Latossolos Neossolos

Nitossolos

Cambissolos

Depósitos Aluvionares

Figura 7 - Detalhe da área em estudo, mostrando a variação do fator de segurança conforme a saturação do solo. 
(saturação em 100\%). Nessas áreas a instabilidade está associada à declividade acentuada e à ocupação desordenada das encostas conforme verificou-se no levantamento de campo.

Figura 8 indica três pontos da encosta do Bairro Industrial (próximo ao ponto 3 do mapa dos pontos descritos e amostrados) que mostram os problemas encontrados nessas áreas que nos cálculos realizados apresentaram $F_{S}<1,5$.

Como é possível observar na figura $8 \mathrm{~A}$, as encostas do Bairro Industrial vêm sendo ocupadas desordenadamente, com a retirada da vegetação e execução
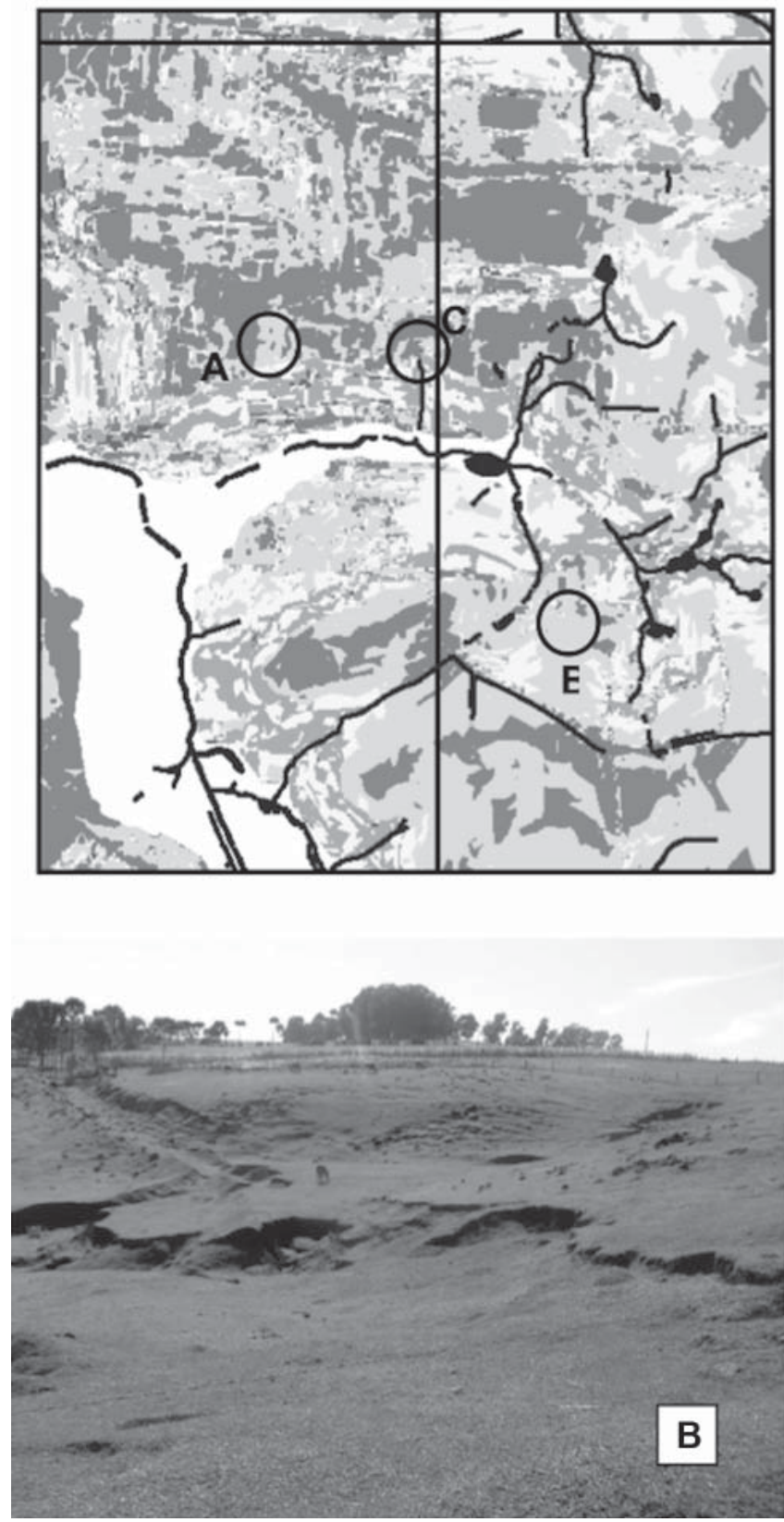

de cortes sem critério algum. A figura 8B mostra áreas ocupadas por Campo, com declividade superior a $20 \%$ e solos do tipo Cambissolos, que apresentam várias marcas de instabilidade, tais como rastejos e erosões. Ainda em relação a obras executadas sem consideração ao meio físico, notam-se diversas ruas, pela cidade, com traçado criando rampas perpendicularmente às curvas de nível (Fig. 8C), as quais servem como canais de concentração das águas de chuva podendo resultar em erosões e inundações.

O bairro Bela Vista está localizado em área com declividade média superior a $30 \%$ e em solo da classe
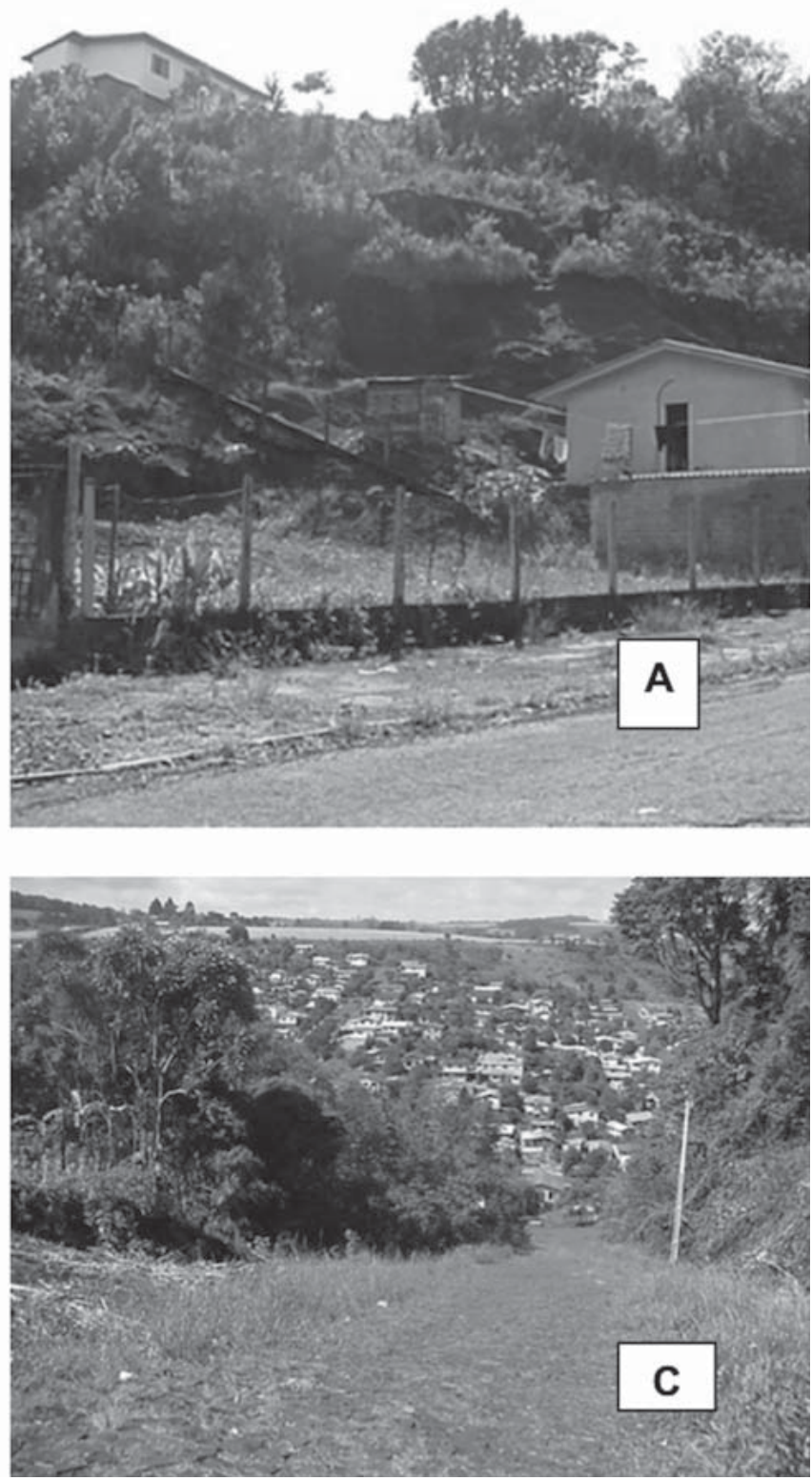

Figura 8 - Detalhe do Bairro Industrial. 
Cambissolo (próximo ao ponto 5 do mapa dos pontos descritos e amostrados). Nessa área, foram realizados diversos cortes para implantar moradias e construção de conjuntos habitacionais conforme mostram as fotos da figura 9. Com a retirada da vegetação e raspagem do solo, e exposição dos Cambissolos que por suas características possuem pouca capacidade de infiltração, forçando as águas pluviais a escoarem superficialmente, provocam o surgimento de sulcos de erosão e até a desestabilizando de casas e da infraestrutura urbana (ruas e sistema de drenagem), fato já detectado anteriormente nessa área.

Empresas de terraplenagem têm provocado a degradação de áreas pois executam cortes e aterros com geometria inadequada deixando o solo exposto e sem proteção, tornando áreas que inicialmente eram estáveis, em taludes altamente instáveis conforme a figura $10 \mathrm{~A}$, que exibe um detalhe de erosão em sulcos no bairro Menino Deus, causada pela falta de proteção do solo. Essas erosões já tinham sido verificadas no ano de 2001, mas ainda hoje nada foi feito para conter esse problema. As figuras 10B, C e D (próximo ao ponto 8 do mapa dos pontos descritos e amostrados) mostram áreas consideradas como de expansão do município, próximas ao Bairro Dall Ross apresentando o surgimento de diversas erosões em sulcos provocadas pelas águas pluviais ao escoarem em solos expostos.

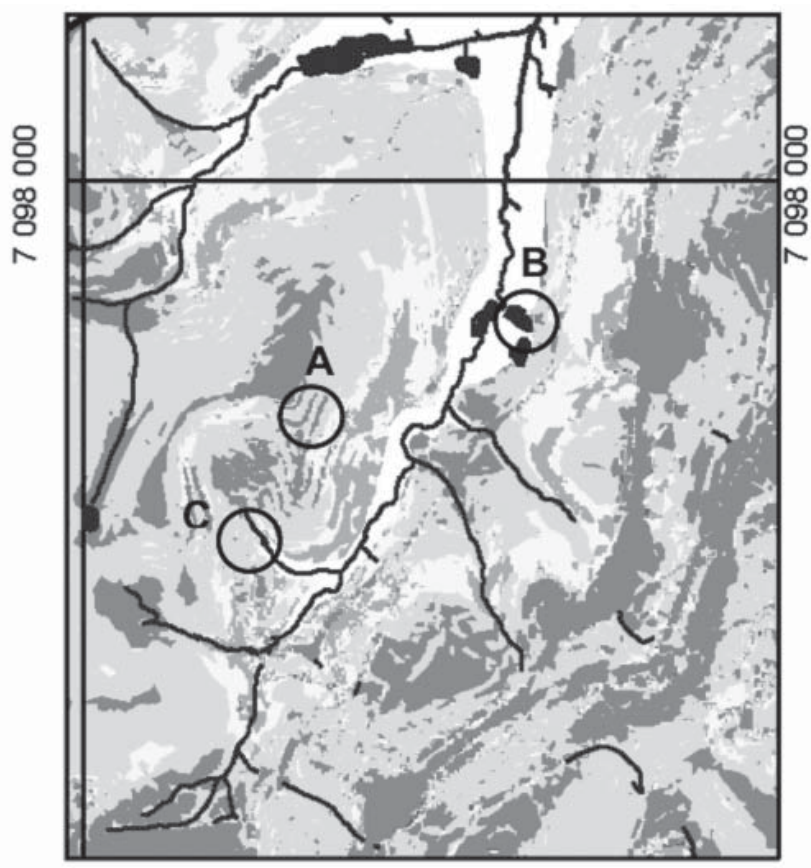

330000

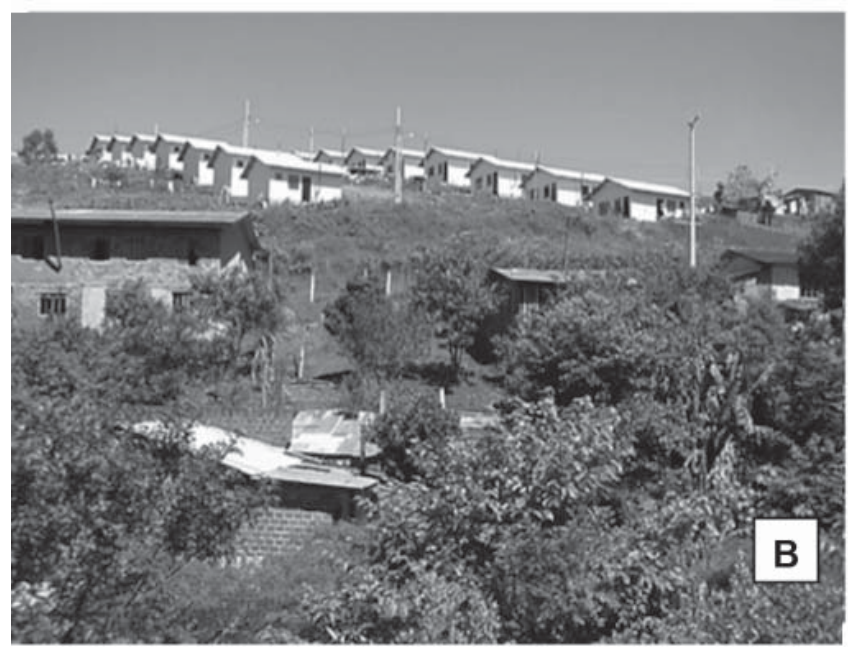

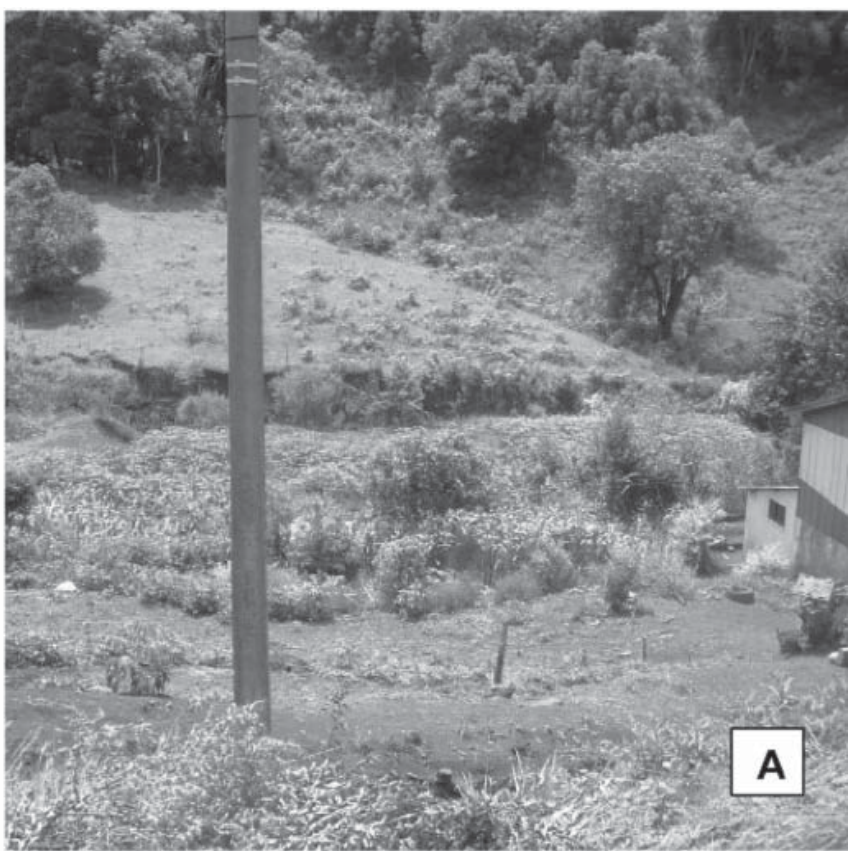

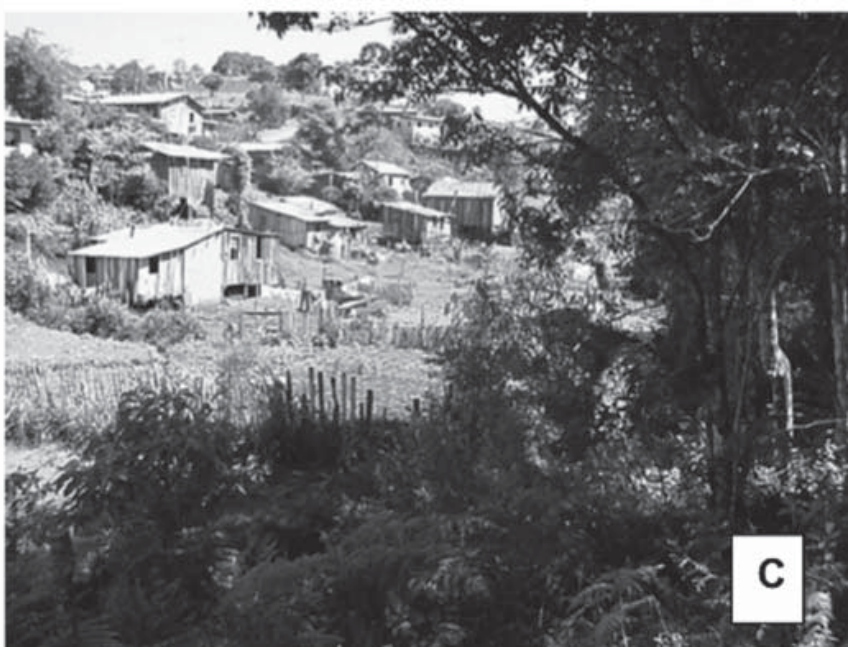

Figura 9 - Detalhes do bairro Bela Vista. 

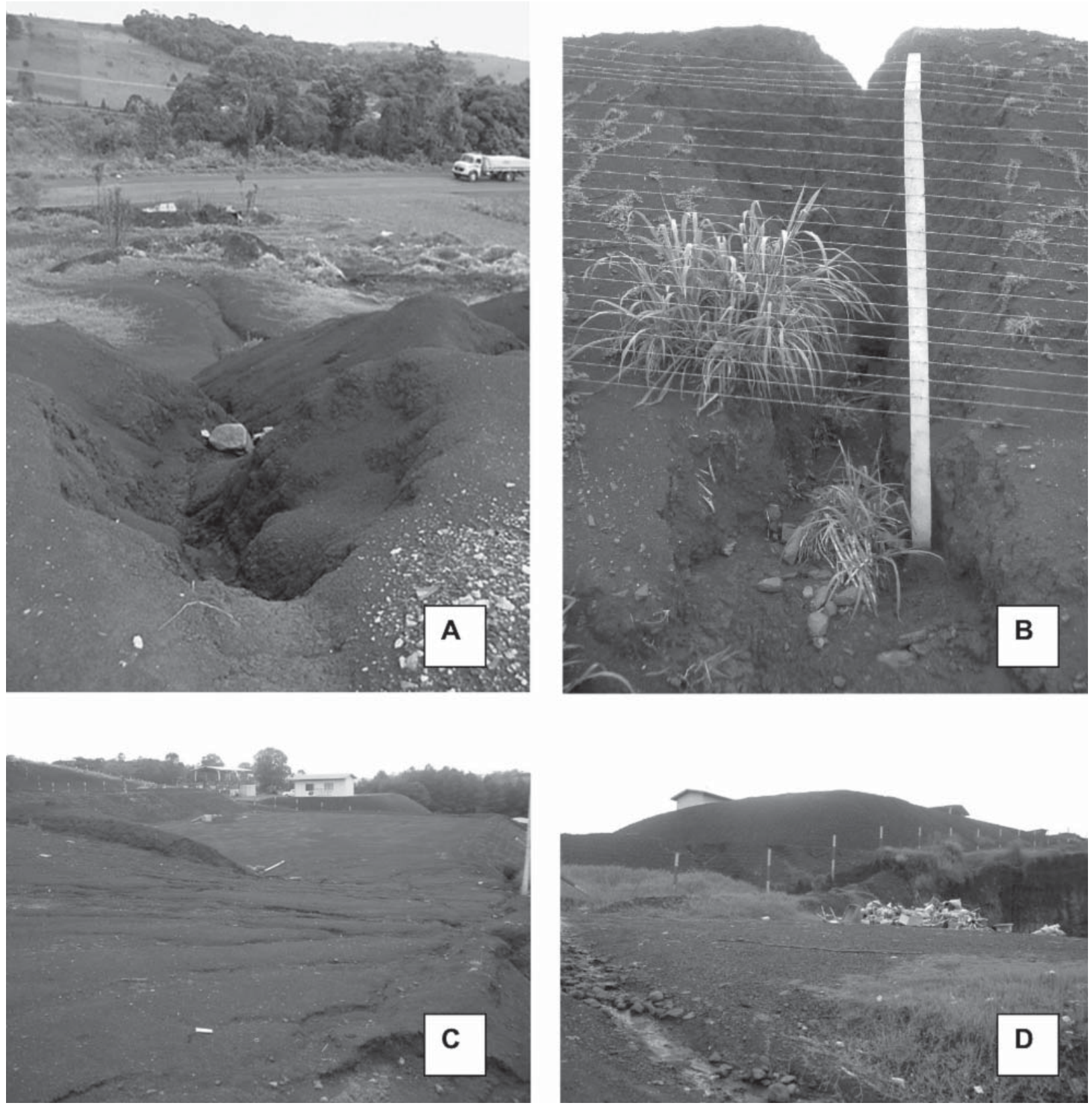

Figura 10 - Áreas de corte e aterro apresentando várias erosões em sulcos.

CONCLUSÕES O objetivo desta pesquisa foi de caracterizar os solos da bacia do Rio Ligeiro no município de Pato Branco, Sudoeste do Paraná, analisando as condições de estabilidade das encostas dessa área.

Os fatores envolvidos na análise de estabilidade foram aplicados em três modelos matemáticos para a análise dos fatores de segurança da área estudada, em função da presença ou não de água no solo. Observa-se que o grau de saturação do solo contribui significativamente para a instabilidade das vertentes, principalmente pela diminuição da coesão do solo.

Os mapas elaborados permitem uma visualização das áreas de risco em relação à instabilização das encostas.
A determinação dos parâmetros físicos e mecânicos do solo em laboratório conduziram a uma melhor caracterização geotécnica dos solos e a uma determinação da resistência dos mesmos a escorregamentos.

Áreas estáveis aparecem com maior frequência nas áreas de solos Latossolos e Nitossolos, por estarem localizados em áreas de baixa declividade, onde o perigo de ocorrência de deslizamento é praticamente nulo.

Constatou-se, através desse estudo, que as áreas mais susceptíveis a escorregamentos estão associadas a encostas com solos do tipo Cambissolo e Neossolo encontrados em áreas com declividade superior a $20 \%$.

Observou-se ainda que, considerando a vertente com umidade natural (seco) e sem vegetação apenas os 
solos da classe Cambissolo, com declividade entre 55 a $60 \%$ apresentaram Fator de Segurança $<1,5$. No caso de vertente não saturada, apresentaram instabilidade os solos Cambissolos com declividade entre 40 e $60 \%$ e Neossolos com qualquer declividade.

Finalmente quando se considerou o solo saturado, apresentaram $F_{S}<1,5$ os solos Cambissolos com declividade entre 30 e $60 \%$, Neossolos com qualquer declividade e Nitossolos e Latossolo com declividade superior a $20 \%$.

Portanto, constatou-se que o solo que apresenta a pior situação em termos de segurança a escorregamentos é o Cambissolo em encostas sem vegetação e o solo que apresenta a melhor situação em termos de segurança a escorregamentos é o Latossolo em encostas com vegetação.

As áreas de ocorrência de Cambissolos e Neossolos correspondem a $84 \%$ das áreas instáveis da bacia quando o solo se encontra totalmente saturado. Isto se deve ao fato de estarem associados a vertente com declividades elevadas e maior quantidade da fração areia na granulometria.
Evidencia-se, através deste trabalho, que a bacia do Rio Ligeiro apresenta áreas com instabilidade com solo saturado, susceptível a escorregamentos, como consequência dos fatores ambientais, do meio físico e da ocupação antrópica das encostas que remove a vegetação.

Assim evidenciou-se que, os mapas de índices de segurança podem se tornar ferramentas indispensáveis para o planejamento territorial e amenização das consequências geradas pelos escorregamentos, permitindo a elaboração medidas de prevenção e mitigação dos riscos direcionando as políticas publicas nas políticas de uso e ocupação de terras.

Enfim, pode-se concluir que a metodologia aqui apresentada mostrou-se satisfatória, apresentando resultados coerentes com a realidade. O conhecimento das limitações e potencialidades dos terrenos possibilitará ao governo municipal tomar decisões em relação ao uso e ocupação do solo, a partir do conhecimento das principais características do meio físico estudado.

\section{Referências}

Barata F.E. 1994. Propriedades mecânicas dos solos: Uma introdução ao projeto de fundações. Rio de Janeiro, Editora Livro Técnico e Científico, 152 p.

Caputo H.P. 1988. Mecânica dos solo e suas aplicações - vol. 2. Rio de Janeiro, Editora Livro Técnico e Científico, 456 p.

CPRM - Companhia de Pesquisa de Recursos Minerais. 1996. Mapa Hidrogeológico da América do Sul. Brasília, DNPM, mapa hidrogeológico, escala 1:5.000.000.

DNER - Departamento Nacional de Estradas e Rodagem. 1996. Manual de Pavimentação. Rio de Janeiro, DNER, $327 \mathrm{p}$.

DSG - Diretoria de Serviço Geográfico. 1981. - Folha topográfica MI - 2862/2, Pato Branco. Pato Branco, mapa topográfico, escala 1:50.000.

DSG - Diretoria de Serviço Geográfico. 1980. - Folha topográfica MI - 2862/4, Mariópolis. Mariópolis, mapa topográfico, escala 1:50.000.

EMBRAPA. 1974. Levantamento de Reconhecimento dos Solos do Sudoeste do Estado do Paraná. Curitiba, EMBRAPA-SNLCS/SUDESUL/IAPAR, Boletim Técnico 40, 79 p.

EMBRAPA. 1984. Levantamento de reconhecimento dos solos do Estado do Paraná. Curitiba, EMBRAPA-SNLCS/ SUDESUL/IAPAR, Boletim de Pesquisa 27, 196 p.

EMBRAPA. 1974. Mapa de Levantamento de Reconhecimento dos Solos do Estado do Paraná. Londrina, mapa geológico, escala 1:600.000.

EMBRAPA. 1999. Sistema Brasileiro de Classificação de Solos. Rio de Janeiro, EMBRAPA, 412 p.

Fiori A.P. \& Carmignani L. 2001. Fundamentos de mecânica dos solos e das rochas: aplicações na estabilidade de taludes. Curitiba, Editora da UFPR, 602 p.
Franciss F.O. \& Rocha H.C. 1998. Obras Subterrâneas Civis. In: Oliveira A.M.S. \& Brito S.N.A. (eds.) Geologia de Engenharia. São Paulo, Oficina de Textos, p. 439-456.

Guidicini G. \& Nieble C.M. 1983. Estabilidade de Taludes Naturais e de Escavação. São Paulo, E. Blücher, 196 p.

IBGE - Instituto Brasileiro de Geografia e Estatística. 2006. Manual técnico de uso da terra. Rio de Janeiro, Série Manuais Técnicos em Geociências 7, 91 p.

Kozciak S. 2005. Análise da estabilidade de vertentes na bacia do Rio Marumbi - Serra do Mar - Paraná. Tese de Doutorado, Setor de Ciências da Terra, Universidade Federal do Paraná, Curitiba, 141 p.

Pinto C.S. 2002. Curso básico de mecânica dos solos em 16 aulas. 2.ed., São Paulo, Oficina de textos, 355 p.

Salomão F.X.T. \& Antunes F.S. 1998. Solos e Pedologia. In: Oliveira A.M.S. \& Brito S.N.A. (eds.) Geologia de Engenharia. São Paulo, Oficina de Textos, p. 87-99.

Tabalipa N.L. 2002. Proposta para o desenvolvimento urbano do município de Pato Branco, Paraná, baseada em critérios geológicos e geomorfológicos. Dissertação de Mestrado, Setor de Ciências da Terra, Universidade Federal do Paraná, Curitiba, 137 p.

Wolle C.M. 1988. Análise de escorregamento translacionais numa região da Serra do Mar no contexto de uma classificação de mecanismos de instabilização de encostas. Tese de Doutorado, Escola Politécnica, Universidade de São Paulo, São Paulo, 800 p.

Manuscrito ID 12026

Submetido em 15 de agosto de 2008 Aceito em 07 de fevereiro de 2012 